\title{
Membangun Ketahanan Keluarga dengan Komunikasi Interpersonal
}

\section{Building Family Security With Interpersonal Communications}

\author{
Muhammad Thariq* \\ Jurusan Ilmu Komunikasi, Fakultas Ilmu Sosial dan Ilmu Politik, \\ Universitas Muhammadiyah Sumatera Utara, Indonesia \\ *E-mail: Muhammadthariq@gmail.com
}

\begin{abstract}
Abstrak
Penelitian bermaksud mengetahui bagaimana komunikasi interpersonal dapat membangun ketahanan keluarga dalam menghadapi tantangan yang semakin berat. Penulis menggunakan metode kualitatifdeskriptif dan menggunakan tiga teknik, yakni observasi, wawancara mendalam dan telaah dokumentasi. Hasil penelitian menemukan, komunikasi interpersonal berperan penting membentuk ketahanan keluarga dan menguatkan fungsi keluarga menghadapi tantangan semakin berat. Komunikasi interpersonal antara orangtua dan anak melalui pemberian pernyataan-pernyataan seperti "kenalilah keluargamu dan ingat siapa dirimu", "kita hidup tidak sendiri" dan "ingat tetangga, ingat keluarga" dapat membentuk konsep diri/karakter anak dan keluarga di tengah masyarakat seperti yang dilakukan para orangtua kepada anak/keluarga di Lingkungan 1 Pasar 6 Kelurahan Tanjungsari Kecamatan Medan Selayang. Terdapat relasi dan tindakan keluarga yang positif atas dasar percakapan, konformitas, ketergantungan serta distribusi kekuasaan yang berasal dari orangtua dan anak sehingga terbangun relasi hangat dan suportif dicirikan dengan saling menghormati, memperhatikan satu sama lain. Komunikasi interpersonal dapat berfungsi membangun relasi antarkeluarga dan relasi sosial dalam bentuk arisan berusia 20 tahun. Komunikasi keluarga di Lingkungan ini (keluarga lama) menjunjung tinggi rahasia keluarga dan pembatasan pada hal yang tabu. Pesan itu disampaikan orangtua kepada anak-anak terutama antar-keluarganya, sehingga keluarga dapat memelihara topik yang tidak lazim disampaikan dalam arisan keluarga. Sikap itu sebagai pengikatan, evaluasi, pemeliharaan, privasi, pertahanan serta komunikasi antar -keluarga.
\end{abstract}

Kata kunci: Relasi Sosial, Komunikasi Interpersonal, Percakapan, Konformitas

\begin{abstract}
This learning how "Interpersonal communication can build a family of endurance in the face of even greater challenges"? The authors use a qualitative method and use careful collection of data such as observation, intimacy, and documentation. The result of this study found that interpersonal communication was very important to implement family resilience and to strengthen the family function in facing the challenges. Interpersonal communication between parents and children through statements such as "know the family and remember who you are", "we live by ourselves" and "remember the neighbors, remember the family" can form the concept of self / character of children and families in the community as Done Parents to children / families in the Neighborhood in Pasar 6 Tanjungsari District of Medan Selayang Subdistrict. There is a positive and positive relationship to a family built on the stage, conformity, dependence, and distribution of the parents 'and parents' power as well as the family, so that the warm and supportive relationships created by mutual respect and coexisting with each other. Interpersonal communication, the family can generate family and social relationships in the 20-year age group. Lastly family communication in Pasar 6 Tanjungsari District of Medan Selayang (old family) uphold family secrets and restrictions on the matter. The message sends parents to the children, especially among their families, to keep their families on topics that are not commonly considered in the family family. This attitude is believed to be the binding, evaluation, maintenance, privacy, defense and interclause communication.
\end{abstract}

How to Cite: Thariq, M. (2017), Membangun Ketahanan Keluarga Dengan Komunikasi Interpersonal, Simbolika, 3 (1): 34-44. 


\section{PENDAHULUAN}

Keluarga adalah tiang penopang utama dalam menjalankan kehidupan terutama untuk tumbuh kembang generasi muda. Keluarga merupakan pendidik pertama dan garda terdepan untuk mewujudkan sumber daya manusia. Untuk itu dukungan total dari keluarga mampu melahirkan seolah-olah mukjizat dalam kehidupan mereka. Begitulah urgensinya fungsi keluarga sebagai organisasi terkecil di dalam struktur masyarakat yang turut memengaruhi karakter dan mental bangsa. Dengan demikian bangsa yang kuat tergantung pada pembangunan keluarga yang baik sehingga keluarga mampu menjadi pilar pembangunan. Namun harapan pada keluarga yang tangguh untuk membentuk karakter dan mental bangsa tidak selalu berbanding lurus dengan kenyataan di masyarakat saat ini. Hal itu seiring dengan tekanan keluarga justru semakin berat karena membesarnya tuntutan ekonomi, perkembangan teknologi hingga perubahan sosial yang semakin berat pula. Akibatnya fungsi keluarga di tengah masyarakat menurun dalam menghadapi persoalan bangsa. Secara perlahan tetapi pasti pelemahan fungsi keluarga tersebut berdampak pada ketahanan keluarga dalam membentuk karakter dan mental bangsa.

Terpaan berbagai persoalan klasik keluarga yang disebutkan di atas seperti ekonomi, pendidikan hingga rendahnya akses terhadap papan yang sehat masih banyak dihadapi keluarga Indonesia. Belum selesai masalah itu, keluarga sudah dihadapkan pada berbagai tantangan baru yang lebih rumit.
Perkembangan

internet, konsumersime, lunturnya penghargaan, rasa hormat dan kepedulian terhadap sesama hingga persoalan peredaran narkotika, ketidakjujuran, korupsi serta radikalisme semakin menggerogoti fungsi keluarga. Belum lagi di sisi lain, globalisasi, meningkatkanya individualisme dan semakin lemahnya kontrol sosial membuat beban yang dihadapi semakin besar.

Ketua Pusat Studi Kesejahteraan Anak dan Keluarga Universitas Padjadjaran Bandung Nunung Nurwati (Kompas: 2017) mengatakan, hanya dengan kuatnya ketahanan keluarga, berbagai persoalan itu bisa dilalui.

Lemahnya peran keluarga hanya akan melahirkan generasi bangsa yang lemah dan penuh masalah. Masih dalam Kompas, menurut Nunung Nurwati, apapun yang terjadi pada bangsa semua bermula dari keluarga. Meski keluarga berperan penting dalam menentukan peradaban bangsa, hingga saat ini pembangunan keluarga masih terpinggirkan. Data dari Kompas 2017, Indonesia memiliki lebih dari 65 juta keluarga. Program pembangunan keluarga yang ada baru terfokus pada pemberdayaan ekonomi.

Seiring dengan program pemberdayaan ekonomi oleh pemerintah, para orangtua atau keluarga perlu mendapat pemahaman tentang pentingnya peran komunikasi interpersonal dalam keluarga. Peneguhan kembali pentingnya peran komunikasi interpersonal di dalam keluarga dinilai dapat mengantisipasi dampak terpaan internet dan teknologi komunikasi perlahan tapi pasti telah mengubah pola 
komunikasi keluarga dan menggerus ketahanan keluarga. Komunikasi dengan tatap muka langsung sebagai ciri-ciri komunikasi interpersonal memungkinkan masing-masing pihak membaca mimik muka, bahasa tubuh, hingga memungkinan belaian atau sentuhan nyaman antara orangtua dan anak akan membentuk realitas kebersamaan dalam keluarga. Suasana itu pada gilirannya dapat mempengaruhi relasi dan tindakan keluarga yang hangat dan suportif yang dicirikan saling menghormati dan saling memperhatikan. Perilaku keluarga seperti itu dapat membentuk karakter anak yang positif pula.

Untuk itu penulis mengkaji dan meneliti kekuatan komunikasi antarpersonal pada masyarakat di Pasar 6 Lingkungan I Kelurahan Tanjungsari Kecamatan Medan Selayang, Kota Medan, yang terlebih dahulu melihat komunikasi berbasis tatap muka di dalam keluarga yang dilakukan para orangtua secara turun temurun dilakukan kepada anak dan cucu-cucunya yang secara tidak langsung memupuk suatu arisan keluarga selama 20 tahun. Bukankah realitas itu sebagai modal ketahanan keluarga di tengah perubahan pola komunikasi yang turut melemahkan ketahanan keluarga, karakter serta mental bangsa saat ini. Penulis berharap hasil penelitian ini menjadi dasar berpijak baik secara teroretis maupun praktis untuk membangun ketahanan keluarga dengan memperkuat komunikasi keluarga di tengah perkembangan internet dan teknologi komunikasi berbasis teks dan suara.

\section{METODE PENELITIAN}

Metode penelitian yang digunakan adalah kualitatif-deskriptif. Pendekatan kualitatif berguna untuk menggambarkan suatu realitas, kondisi keluarga, relasi serta tindakani dalam masyarakat.

Teknik pengumpulan data dalam penelitian ini dilakukan dengan tiga cara, yaitu (1) observasi melalui pendekatan peran serta, (2) wawancara mendalam dan (3) penggunaan dokumen. Observasi melalui pendekatan peran serta untuk mengungkapkan fenomena di lapngan peneliti menggunakan teknik pengamatan. Pengamatan yang dimanfaatkan adalah pengamatan yang berperan serta atau engamatan yang terlibat. Pengamatan terlibat adalah pengamatan yang dilakukan smabill sedikit banyaknya berperan serta dalam kehidupan yang diteliti. Pengamatan terlihat mengikuti orang-orang yang diteliti dalam kehidupan sehari-hari mereka, melihat apa yang (Becker dalam Mulyana, 2001: 162)

Dalam hal ini penulis melakukan pengamatan dan berperan serta pada masyarakat di Pasar 6 Lingkungan I Kelurahan Tanjungsari, Kecamatan Medan Selayang, Kota Medan, serta mengamati realitas komunikasi antara orangtua dan anak serta relasi antar keluarga dan interaksi.

Teknik pengumpulan data dengan wawancara terbuka atau mendalam yang memberi keleluasaan bagi informan untuk memberi pandangan-pandangan secara bebas. Wawancara demikian ini memungkinkan si peneliti untuk mengajukan pertanyaan-pertanyaan seara mendalam. Karena itu untuk melengkapi data penelitian ini, khususnya dalam upaya memperoleh data yang akuran 
tentang penelitian ini, peneliti akan melakukan wawancara dengan informan. Dalam penelitian ini wawancara yang akan digunakan adalah wawacara yang mendalam atau wawancara tak berstruktur. Wawancara tak berstruktur mirip dengan percakapan informal bersifat luwes, susunan pertanyaan atau kata-kata dapat diubah saat wawancara dilaksanakan, disesuaikan dengan kebutuhan dan kondisi informan yang dihadapi (Mulyana, 2001: 181).

\section{HASIL DAN PEMBAHASAN}

Jumlah kepala keluarga yang mendiami Pasar 6 Lingkungan I Kelurahan Tanjungsari Kecamatan Medan Selayang lebih kurang 600 kepala keluarga, sementara yang tercatat dalam Pemilihan Umum sekitar $300 \mathrm{KK}$ atau 2.500 jiwa yang terdiri dari berbagai macam etnis yang mana etnis Jawa menjadi mayoritas dan urutan kedua adalah etnis Batak selebihnya ada etnis Sunda, Aceh dan Melayu, sedangkan mayoritas penduduknya memeluk agama Islam.

Mengenai bahasa sehari-hari adalah Bahasa Jawa di lingkungan itu hampir merata digunakan oleh penduduk asli di sana hingga generasinya sekarang. Hidup rukun dan tenteram menjadi suasana di lingkungan tersebut, belakangan suasana sosial diwarnai hiruk-pikuk peredaran bebas narkotika, internet, perubahan lanskap kota akibat pelebaran jalan, pendirian rumah bercorak rumah toko, hadirnya tempat penginapan, rumah kos serta aktivitas bisnis. Sebagian bangunan baru itu proses alih fungsi rumah semi permanen dengan halaman yang luas peninggalan orangtua. Kebanyakan rumah-rumah lama itu semi permanen dengan tanah dan halaman yang luas. Mereka tinggal beriringan dengan saudara-saudara yang masih memiliki hubungan kekerabatan.

Alih fungsi bisa disebabkan pembagian harta warisan kepada anakanaknya dan sebagian berpindah tangan sementara atau permanen kepada orang lain dari generasi kedua masyarakat di sana. Dari situ model kehidupan di sana mulai terlihat lebih pragmatis karena tuntutan ekonomi, pergerakan kota, laju urbanisasi pencari kerja (buruh dan perkantoran), kuliah serta faktor yang disebabkan perkawinan. Alhasil banyak kaum pendatang baik perempuan maupun laki-laki yang relatif muda. Mereka ada yang indekos dan membeli tanah serta rumah yang dijual penduduk lama. Namun interaksi kaum pendatang tidak serta merta mempengaruhi sistem kekerabatan penduduk lama bahkan warga baru sulit melekat dalam aktivitas relasi apapun yang sudah terbangun lama seperti perwiritan, pengajian dan arisan antarkeluarga inti. Jangan heran di Pasar 6 ini terdapat sistem keluarga lama dan keluarga baru sehingga fungsi keluarga berbeda.

Kepala Lingkungan I Endang Wahyudi, 40, yang juga menjadi informan peneliti di lapangan mengakui keterangan di atas. Endang merupakan generasi kedua dari penduduk lama yang hidup berkelompok membangun relasi keluarga yang cukup kental dalam bentuk arisan atau pengajian dari gang satu ke gang lainnya di sepanjang Pasar 6 tersebut. Dia menjabat sebagai kepala lingkungan atas warisan almarhum Suratman, orangtuanya yang sebelumnya juga sebagai kepala lingkungan cukup lama di sana 
menggantikan almarhum H Rasyim. Dia mengatakan sekitar 10 atau 15 kepala keluarga lama (generasi pertama) hidup menyebar di sekitar 10 gang di lingkungannya yang membangun relasi antar-keluarga generasi penerus (generasi kedua dan ketiga atau cucu). Satu dari 15 kepala keluarga itu memiliki beberapa anak (generasi kedua) yang menghasil cucu. Satu keluarga (generasi pertama) terkadang memiliki 10 anak yang kemudian membentuk relasi sosial dengan mendirikan pengajian dan arisan sampai berusia 20 tahun. Arisan itu masih berjalan.Begitu juga kaum mudanya menyatu atau berelasi dalam wadah paguyuban kepemudaan.

\section{Ada}

pernyataan-pernyataan orangtuanya yang masih dia ingat sekaligus menjadi perekat relasi antarkeluarga di sana sampai sekarang, yaitu "kenalilah keluargamu dan ingat siapa dirimu" dan "kita hidup tidak sendiri". Selain itu ada kalimat lain "ingat tetangga, ingat keluarga." Pernyataan itu disampaikan orangtua kepada anaknya atau anggota keluarga lebih besar, baik dalam keluarga inti maupun dalam kesempatan-kesempatan tertentu.

Pernyataan-pernyataan itu sebagai satu tanggung jawab utama yang dimiliki para anggota keluarga atau disebut "berbicara atau percakapan" keluarga meliputi unsur-unsur komunikasi verbal dan nonverbal. Cara-cara itu berkontribusi bagi pengembangan konsep diri yang kuat bagi semua anggota keluarga, terutama pada anak-anak muda (Yerbi, BuerkelRothfuss, \& Bochner, 1995). Bahkan D.H Demo (1987) menekankan pada maksud bahwa konsep diri dibentuk, dipelihara, diperkuat, dan/atau diubah oleh komunikasi dari para anggota keluarga. Lebih lanjut (Budyatna \& Ganiem: 170) bahwa konsep diri para anggota keluarga ditingkatkan dengan cara sebagai berikut: 1). Pernyataan pujian: "Yanto, luar biasa Anda telah bermain cantik pada pertandingan kompetisi bola basket tadi sore". 2). Pernyataan sambutan dan dukungan: "Joko, bila mempunyai alasan yang kuat untuk membatalkan keikutsertaan Anda mendaki gunung, kami dapat menerima keputusan Anda". 3). Pernyataan kasih: "Sonny, saya dapat merasakan betapa menyakitkan bermain buruk dalam pertandingan bulu tangkis tadi di hadapan keluarga, tetapi kita sang kepada Anda dan akan hadir pada pertandingan berikut".

Pernyataan verbal dan non-verbal dalam sebuah komunikasi keluarga seperti di atas sangat strategis untuk mendorong pada tataran tindakan sesuai apa yang tersirat dari pesan tersebut. Hal itu dikuatkan oleh John Greene yang pertama kali mempublikasi Teori Pengumpulan Tindakan bagian dari Teori Komunikasi Interpersonal pada 1984. Teori ini berusaha menjelaskan dari mana pemikirran kita berasal dan bagaimana kita menerjemahkan pemikiran ini ke dalam komunikasi verbal dan nonverbal. Dia mengemukakan bahwa orang mengorganisasikan dan menyimpan pengetahuan tentang makna sesuatu dan bagaimana melakukan tindakan sesuatu serta kemudian menggunakan pengetahuaan itu dalam tindakan. Ketika orang bertemu dengan situasi serupa, mereka mengingat, atau mengumpulkan, memori ini dan merancang arah tindakan (Littlejohn \& Foss: 662). 
Endang merasakan pernyataan yang membentuk konsep atau karakter dirancang menjadi tindakan perengkat antarkeluarga. Dia mengakui pernyataan itu sebagai modal kuat menempa ketahanan keluarga dan relasi sosial di lingkungannya terutama dalam menghadapi tantangan serta persoalan yang semakin pelik. Endang juga mengaku tidak tahu apakah warisan orangtua ini berlaku pada 10 atau 20 tahun yang akan datang sebab indikasi ketahanan dan fungsi keluarga melemah pada aspek komunikasi keluarga seperti di atas. "Saya pesimis relasi antar-keluarga pada generasi selanjutnya dapat dilanjutkan," katanya.

Endang memberikan pandangannya bahwa orangtua sekarang di lingkungannya banyak yang tidak meneruskan cara komunikasi keluarga yang di dalamnya turut memberikan sumbangan bagi pembentukan konsep diri atau karakter anak. Padahal prinsip komunikasi keluarga ini menunjukkan bahwa pentingnya pesan dan relasi dalam komunikasi interpersonal. Orang punya banyak pilihan komunikasi. Satu tujuan komunikasi dapat dicapai melalui banyak pesan berbeda-beda dan satu pesan dapat memenuhi banyak tujuan berbeda-beda (Littlejohn \& Foss: 661).

Terlepas dari bagaimana tantangan masa depan generasi berikutnya, kini generasi penerus orangtua dan kerabatnya (generasi kedua) di Pasar 6 telah berfungsi membangun relasi antar-mereka sampai sekarang dalam bentuk pengajian, wirit dan arisan. Hal ini sejalan dengan pernyataan bahwa kebanyakan fungsi mengenai sistem keluarga merupakan produk dari komunikasi di dalam keluarga (Budyatna dan Ganiem: 168).

Informan yang lain, Susilo berusia 65 tahun, mengatakan pola komunikasi keluarga itu memunculkan istilah keluarga lama dan keluarga baru di lingkungannya. Dia mengaku merasakan sendiri hangat dan suportifnya relasi keluarga lama karena memang diwariskan oleh orangtua di lingkungannya. Tokoh masyarakat yang biasa menjadi imam di Masjid Nurul Mukminin di Pasar 6 ini disapa Lek Silok dalam keluarga dan masyarakat. Pekerjaannya sehari-hari sebagai pekerja lepas bangunan. Orangtuanya meninggalkan sejumlah petak tanah dan rumah di sana. Lokasi rumah dan warisan almarhum orangtuanya hanya berjarak beberapa meter dari rumahnya sekarang. Dia menikah dengan Rasmiati, anak kedua dari 11 bersaudara dari pasangan almarhum $\mathrm{H}$ Rasyim dan almarhumah $\mathrm{Hj}$ Mariati. Mertua Lek Silok ini salah satu orang lama atau bisa disebut sebagai generasi pertama di Pasar 6 yang juga memiliki sejumlah petak tanah dan rumah induk yang luas persis berada di pinggir Jalan Kenanga Raya. Sepeninggal Kek Rasyim dan Nek Mariati, rumah dan tanah dibagi-bagi untuk anaknya.

Kini enam anaknya (generasi kedua) mendiami rumah tersebut secara berdampingan. Pembagian tanah dan bangunan rumah induk hanya dipisah dengan sekat dinding batu bata. Rumah yang menghadap jalan dibentuk semi rumah toko. Anak-anak Kek Rasyim hidup dengan berwirausaha warisan orangtua mereka, di depan rumah seperti menjual sarapan pagi, sop, kelontong dan sebagian pembagian tanah dan rumah sudah berpindah tangan tetapi pembelinya 
masih kerabat dekat dari orangtua mereka dulu. Sedangkan anak laki-laki Kek Rasyim memilih sebagai pekerja lepas. Dahulunya Kek Rasyim dan istrinya tidak memiliki jenjang pendidikan yang memadai begitu juga pada kebanyakan anaknya berhenti di bangku sekolah dasar. Begitupun Kek Rasyim pernah menjadi orang berpengaruh di lingkungan tersebut karena dia figur yang pandai menghormati, menghargai, ulet serta mudah membangun relasi sehingga diangkat menjadi kepala lingkungan semasanya di Pasar 6 tersebut. Kek Rasyim dan orangtua-orangtua semasanya di masyarakat tersebut, termasuk orangtua Lek Silok dan Endang disebut keluarga lama yang anak-beranak (generasi kedua) tetap membangun relasi sosial dalam bentuk arisan keluarga dan pengajian yang sudah 20 tahun masih ada.

Kembali kepada Lek Silok, dia dan keluarganya termasuk yang mendapatkan pembagian rumah dan menetap di deretan rumah pembagian mertuanya Kek Rasyim. Selanjutnya, Lek Silok dan istrinya mempersilakan empat anak-menantunya menempati rumah bagian dari pembagian orangtuanya di Gang Wiria satu orang tinggal bersamanya. Mereka tinggal dari gang ke gang. Dengan demikian basis keluarga lama terpola dalam kekerabatan yang hidup berdampingan. Demikian juga keluarga Kek Rasyim, meski peninggalan rumah induknya di depan Jalan Kenanga Raya tetapi letak rumahnya masuk bagian Gang Perdamaian. Begitu juga di gang itu terdapat beberapa petak tanah dan rumah peninggalannya. Sebagian sudah dijual tersisa satu petak tanah dan rumah yang kini ditempati anak pertama perempuan bernama Rasmi (generasi kedua) yang kini sudah memiliki tujuh cucu. Dua anak ibu Rasmi yang sudah menikah tinggal di rumah tersebut juga turut menyambung relasi antar-keluarga di sana dengan mengikuti pengajian dan arisan.

Menurut Lek Silok, keluarga lama terbentuk dari generasi penerus orangtua yang pertama menetap lingkungan tersebut, sedangkan keluarga baru adalah orang pendatang atau urban sebagai pencari kerja, kuliah, membuka bisnis, kantor dan lain-lain. Untuk itu jarang terjadi keributan atau konflik yang mendasar. Semua permasalahan keluarga dan kemasyarakatan dibawa dalam arisan, pengajian, saling maaf bermafaan menjelang masuk Ramadhan dan perkumpulan generasi muda. Saling kunjung dan salam-salaman terutama pada Idul Fitri yang dilakukan para orangtua dulu masih berjalan sampai sekarang. Sarana relasi sosial itu selalu ada percakapan-percakapan tentang kabar anak, cucu, saudara sampai situasi lingkungan yang terkini. Dengan modal "berbicara sambil mengisap rokok" antarkeluarga biasanya akan menemui solusi. Begitu juga dengan permasalahan kemalangan dan pesta pernikahan dapat ditangani bersama-sama tanpa mengedepankan uang.

Lek Silok mengatakan komunikasi keluarga dengan pernyataan kasih, sambutan dan dukungan serta pujian dari orangtua dulu berkontribusi bagi pembentukan konsep diri menjadi tanggung jawab utama yang dimiliki para anggota keluarga dari orangtua mereka sejak dulu sampai sekarang. Selain itu, komunikasi keluarga dan interaksi satu dengan lain dengan cara mengakui dan mendukung para sanak saudara secara 
individul. Selain itu memberikan rasa nyaman dalam berkeluarga. Para orangtua mereka dulu tidak sibuk dengan urusan pekerjaannya seperti tuntutan sekarang ini yakni pergi pagi pulang malam bahkan lembur dan jauh dari tempat tinggal, melainkan hanya berwirausaha di rumahnya serta memanfaatkan tenaga sambil berwirausaha. Dengan kondisi tersebut komunikasi keluarga yang selalu memberikan pengakuan dan dukungan yang diperlukan dari orangtua kepada anak-anaknya.

Menurut Lek Silok, jarang komunikasi keluarga menonjolkan pertentangan atau tidak saling dukung. Pria yang memiliki enam cucu ini mengatakan suasana masyarakat di sini adem ayem, meski membesarnya tuntutan ekonomi, perkembangan teknologi hingga perubahan sosial yang semakin cepat membuat keluarga menghadapi tantangan yang semakin berat. Dia mengakui beberapa tuntutan di atas mempengaruhi fungsi keluarga tetapi hal itu dapat diantisipasi dengan berinisiatif menggerakkan ekonomi kecil dengan berjualan dan lain sebagainya di depan rumah atau tempat yang lain.Selain itu relasi anak mudanya terjaga dengan baik dalam organisasi seperti karang taruna atau membuat organisasi paguyuban. Relasi ini dibangun tidak terlepas dari konsep diri yang ditanamkan para orangtua melalui tindakan dan komunikasi keluarga.

Dalam wawancara selanjutnya, Lek Silok mengatakan hampir rata orangtua dari keluarga lama mewariskan jiwa berwirausaha dan pekerja lepas. Secara tidak langsung dua pekerjaan itu menular kepada anak dan menantunya. Halaman rumah yang luas peninggalan orangtua dimanfaatkan untuk berdagang dengan membuat kios kecil-kecilan di depan rumah atau membangun indekos beberapa petak, sedangkan suaminya sebagai pekerja lepas. Dengan demikian persoalan tuntutan ekonomi yang menerpa saat ini tidak sampai terlalu dalam melemahkan fungsi keluarga yang berkepanjangan apalagi sampai memicu konflik yang mendasar. Para orangtua keluarga lama mewariskan relasi interpersonal yang baik begitu juga kepribadian yang baik, beragama yang baik, kesehatan fisik dan mental yang lebih baik, saling memenuhi kebutuhan sosial yang baik semasa hidupnya antar-seusia mereka juga yang menjadi orangtua dari para generasi kedua saat ini yang meneruskan modal kepribadian para orangtuanya sampai sekarang. Unsur di atas sebagai bagian dari penentu dalam cakupan komunikasi interpersonal (Littlejohn \& Foss: 658).

Murniati berusia 60 tahun yang juga informan dalam penelitian ini menguatkan bahwa arisan yang mereka bangun sudah 20 tahun. Dia adalah adik kandung dari almarhumah $\mathrm{Hj}$ Mariati penduduk lama yang masih hidup telah membangun komunikasi keluarga yang akrab antar anggota keluarga dan relasi sosial.Komunikasi antara anak-anak, orangtua, eyang dapat menjadi sumber kegembiraan.

Dari wawancara dengan Nek Murniati yang juga masih sebagai pengurus arisan terungkap bahwa Kek Rasyim sampai pada usia 80 dan $\mathrm{Nek} \mathrm{Hj}$ Mariati berusia 76 tahun, sebelum meninggal, tetap memberikan kasih sayang secara timbal balik pada tingkat 
tinggi kepada anak dan cucu-cucunya secara berkesinambungan. Williams dan Nussbaum (2001) menemukan banyak faktor yang menjelaskan bagi kekuatan hubungan anak-orangtua yang berumur 70 tahun atau lebih yakni adanya ubungan orangtua -anak yang kekal tetap memuaskan apabila adanya hubungan yang tetap.

Selain itu, meski sudah berumur lanjut, menurut Murniati, mereka berdua dan orangtua semasanya tetap memberikan dukungan sosial dan bantuan yang nyata serta adanya kesepakatan mengenai nilai-nilai, keyakinan dan pernyataan-pernyataan moral yang membentuk konsep diri seperti "sesama adik-beradik jangan saling cemburu", "hidup rukun", "jangan pelit", "jangan lupa shalat" dan "bangun hubungan silaturahim dan saling kunjung mengunjungi". Sedangkan kesepakatan tentang nilai dan keyakinan yang dibangunnya dalam keluarga yakni saling gotong royong. Tidak hanya pernyataan saja, Kek Rasyim dan istrinya meninggalkan kebiasaan berkumpul dengan sesama anak-menantu serta cucunya di rumahnya setiap menjelang masuk bulan Ramadhan untuk saling bermaafan dan berkunjung dari rumah ke rumah pada Idul Fitri. Menurut Murniati, cara komunikasi keluarga dan kebiasaan yang dibangun itu terus dilaksanakan oleh penerusnya sekarang sehingga terbangun karakter bagi generasi penerusnya tetap saling menghormati dan saling memperhatikan antar keluarga.

Orientasi percakapan memang terbangun lama di masyarakat Lingkungan I Kelurahan Tanjungsari Masih dalam Berger, orientasi percakapan mengacu kepada komunikasi yang terbuka dan sering di antara orangtua dan anak-anak dengan tujuan menggali bersama makna lambang-lambang dan objek yang merupakan lingkungan sosial keluarga. Hal ini terkait dengan hubungan yang hanya bersifat mendukung yang ditandai oleh sikap saling menghormati dan kepedulian satu terhadap yang lain. Begitu juga pola komunikasi dengan orientasi kepenurutan juga terbangun dalam komunikasi keluarga antara orangtua dengan anak yang turut menyumbang dalam membangun ketahanan keluarga. Sebagian besar pesan kebaikan dan konsep diri datang dari orangtua langsung di antaranya pesan pentingnya saling kunjung mengunjungi antar saudara di lingkungan tersebut dan menyekolahkan anak di pesantren. Orangtua memegang kewenangan untuk memberikan pendapat, respons dan tindakan atas realitas sosial (Berger at al: 689).

Anak Ibu Rasmi, Ridho usia 35 tahun, masih generasi ketiga dari keluarga lama di sana juga sebagai informan penulis mengungkapkan keterangan di atas dapat dirasakannya sampai sekarang. Dia juga sampai sekarang terlibat dari arisan yang usianya sudah 20 tahun lebih yang dibangun oleh nenek dan kakek (orangtua mamak). Ada yang khas pada komunikasi keluarga pada masyarakat lama di sana yaitu menjunjung tinggi rahasia keluarga dan pembatasan pada hal-hal yang tabu. Pesan itu disampaikan orangtua kepada anak-anak terutama antar-keluarganya, sehingga keluarga di sana memelihara topik-topik yang tidak lazim disampaikan dalam arisan keluarga sekalipun. Sewaktu almarhum Usman AS, suami dari Ibu Rasmi, anak pertama dari almarhum Kek Rasyim, masih hidup, pernah 
menyampaikan hal itu kepada anak dan menantunya terkait dia menjual tanah dan uangnya akan dia gunakan untuk naik haji. Setelah beberapa bulan Pak Usman meninggal baru tersebar informasi di kalangan keluarga tetapi itu pun masih terbatas bahwa Pak Usman sudah menabung dana haji, dan almarhum sudah haji melalui proses pembadalan atau menggantikan haji melalui orang lain tetapi syaratnya orang yang sudah pernah pergi ke tanah suci. Sebagian keluarga yang sudah tahu merasa terharu dan terkejut atas informasi tersebut. Hal itu disampaikan anak almarhum. "Dan kami tidak ada memberitahu kepada siapapun sewaktu bapak masih ada, baik kepada mertua atau kepada saudara sekandung dari pihak bapak dan mamak," kata Ridho.

Ridho mengungkapkan pesan bapak waktu itu,"jangan disampaikan kabar ini (menabung haji) kepada orang lain. Informasi ini baru sebatas keluarga kita saja dahulu yang tahu untuk menghindari anggapan macam-macam, apalagi uangnya dari penjualan tanah warisan kakek (orangtua Pak Usman)". Menurut Ridho, komunikasi keluarga ini berlaku pada generasi penerus orangtua kami. Pesan yang mau ditularkan kepada anaknya, menurut Ridho, bahwa bagi orangtua pengungkapan rahasia dianggap mengurangi arti dan keakraban hubungan keluarga dan anggota keluarga bisa menggunakan pengungkapan untuk menegaskan otonomi dan kemandirian yang lebih besar dari keluarga (Berger et al: 690).

Menurut Ridho, fungsi rahasia pada dasarnya diyakini keluarga bersifat positif bagi hubungan keluarga. Vangesti (1994) mengatakan hal yang bersifat positif itu berkaitan dengan pengikatan, evaluasi, pemeliharaan, privasi, pertahanan dan komunikasi.

Pola-pola komunikasi keluarga yang dibangun atas dasar komunikasi interpersonal pada keluarga lama di Pasar 6/Lingkungan I Kelurahan Tanjungsari Kecamatan Medan Selayang membuat keluarga pada masyarakat tersebut menjalankan fungsinya dan memiliki ketahanan yang kuat dengan sejumlah proses keluarga seperti penyelesaian konflik (Koerner \& Fitzpatrick, 1997), penguatan dan rasa sayang (Schrodt, Ledbetter, \& Ohrt, 2007), ritual keluarga (Baxter \& Clark, 1996) dan sikap saling pengertian (Sillars, Koerner, \& Fitzpatrick, 2005), disamping dengan hasil-hasil terkait anak seperti kecemasan berkomunikasi (Elwood \& Schrader, 1998), keuleten (Fitzpatrick \& Koerner, 2005) dan kesehatan mental dan fisik anak (Schrodt \& Ledbetter, 2007).

\section{SIMPULAN}

Komunikasi interpersonal berperan penting dalam membentuk ketahanan keluarga dan menguatkan fungsi keluarga dalam membentuk karakter generasi muda bangsa di tengah tantangan keluarga yang semakin berat seperti yang terjadi pada keluarga lama di Pasar 6 Lingkungan I Kelurahan Tanjungsari Kecamatan Medan Selayang yang sebelumnya para orangtua mewariskan modal komunikasi keluarga yang membentuk konsep diri pada anakanaknya (generasi kedua dan ketiga) melalui pernyataan-pernyataan seperti "kenalilah keluargamu dan ingat siapa dirimu", "kita hidup tidak sendiri" dan "ingat tetangga, ingat keluarga." Terdapat 
relasi dan tindakan keluarga yang positif dibangun atas dasar percakapan, konformitas, ketergantungan serta distribusi kekuasaan yang berasal dari orangtua dan anak seperti pada keluarga di Pasar 6 Lingkungan I Kelurahan Tanjungsari, Kec. Medan Selayang, sehingga terbangun relasi yang hangat dan suportif yang dicirikan dengan saling menghormati dan saling memperhatikan satu dengan lainnya. Dengan modal komunikasi interpersonal, keluarga dapat berfungsi dalam membangun relasi antarkeluarga dan relasi sosial selama 20 tahun seperti arisan dan pengajian siang atau malam yang diisi tausiyah agama oleh seorang ustadz. Pertemuan tersebut sebagai sarana untuk menanamkan sifat kesabaran, kekhusyukan, rasa takzim atas nikmat yang diberikan Sang Maha Kuasa kepada salah satu keluarga. Selain itu mendoakan para orangtua dan keluarga yang ditimpa musibah seperti sakit atau meninggal dunia. Komunikasi keluarga pada keluarga lama di Pasar 6 Lingkungan I Kelurahan Tanjungsari Kecamatan Medan Selayang menjunjung tinggi rahasia keluarga dan pematasan pada hal-hal yang tabu. Pesan itu disampaikan orangtua kepada anak-anak terutama antarkeluarganya, sehingga keluarga di sana memelihara topik-topik yang tidak lazim disampaikan dalam arisan keluarga sekalipun. Sikap seperti itu diyakini sebagai pengikatan, evaluasi, pemeliharaan, privasi, pertahanan dan komunikasi antar -keluarga.

\section{DAFTAR PUSTAKA}

Berger, C.R., Roloff, M.E \& Ewoldsen, D.R.R (2011). Handbook Communication Science. USA: Wadswoth.
Budyatna, M dan Ganiem, L.M (2011). Teori Komunikasi AntarPribadi, Jakarta: Prenada Kencana.

Baxter, L.A., \& Clark, C.L. (1996). Perceptionss of family communication patterns and the enactment of family rituals. Western Journal of Communications, 6o, 254-268.

Demo, D.H, (1987). Family Ralations And The Self-Esteem of Odalescent and Their Parents. Journal of Marriage and Family. Vol. 49.

Elwood, T.D., \& Shrader, D.C., (1998). Family communication patterns and communication apprehesion. Journal of Social Behavior an Personality, 13, 493-502.

Fitzpatrick, M.A., \& Koemer, A.F. (2005). Family communication schemata within schemata: Effect on children's resiliency, In S. Dunwoody, L.Becker, D.McLeod, \& G. Kosicki. (eds.)

Koerner, A.F., \& Fitzpatrick, M.A (1997). Family type and conflict: The impact of conversation orientation and conformity orientation on conflict in the family. Communication Studies, 48, 59-75

Littlejohn, S.W \& Foss, K. A (2016), Encyclopedia of Communication Theory, AS: Sage Publication Inc.

Pujileksono, S., (2015). Metode Penelitian Komunikasi Kualitatif, Malang: Intrans Publishing.

Schrodt, P., Ledbetter, A.M., \& Ohrt, J.K (2007). Parental confirmation and affection aas mediators of family communication pattern and children's mental well-being. Journal of Family Communication, 7, 23-46.

Sillars, A., Koerner, A.F., \& Fitzpatrick, M.A (2005). Communication and understanding in parent-adolescent relationships. Human Communication Research, 31, 103-128.

Schrodt, P., \& Ledbetter, A.M. (2007). Communication processes that mediate family communication patterns and mental well-being: A mean and covariance structures analysis of young adult from divorced and non-divorced families. Human Communication Research, 33, 330-356

Vangelisti, A.L., (1994). Family secrets: Forms, functions and correlaters. Journal of Social and Personal and Personal Relationship, 11, 113-135.

Wiliam, A dan Nussbaum, J.F, (2001). Intergenerational Communication Across The Lifepain. Mahwah, N.J.: Erlbau 